ARTICLE

\title{
Collaborative Governance on Ecotourism: Towards Sustainable Tourism Development
}

\author{
Sri Mulyani ${ }^{*}$, Retno Dewi Pramodia Ahsani ${ }^{1}$, and Daya Negri Wijaya ${ }^{2}$ \\ ${ }^{1}$ Department of Public Administration, Faculty of Social and Political Sciences, Universitas Tidar, \\ Kabupaten Magelang, Indonesia. \\ ${ }^{2}$ Doctoral Researcher, University of Porto, Portugal.
}

How to cite: Mulyani, S., Ahsani, Retno D A., \& Wijaya, Daya N. (2021). Collaborative Governance on Ecotourism: Towards Sustainable Tourism Development. Jurnal Borneo Administrator, 17 (3), 319-334. doi: https://doi.org/10.24258/jba.v17i3.958

\section{Article History}

Received: 31 August 2021

Accepted: 16 November 2021

\section{Keywords:}

Collaborative Governance,

Ecotourism,

Sustainable Development, Sustainable Tourism

Development

\begin{abstract}
This study analyses collaborative governance in sustainable ecotourism development in Magelang Regency, Central Java province. Strengthening the collaboration of the three actors is needed in developing ecotourism because it comprehensively regulates natural destinations responsible for the sustainability of natural life, economic activity, and community welfare simultaneously. To explain further the fundamental phenomena that occur in sustainable development. The goal is to create a new environmental friendly concept while also improving people's welfare, the economy, and peaceful social activities. Data were collected from in-depth interviews and observations. Interviews were conducted with 8 local government staffs, 22 ecotourism managers, and 42 communities around the destination. Then an analysis was carried out with Nvivo12+ to see the collaboration of sustainable Ecotourism governance in Magelang Regency. Three variables become benchmarks in the study: planning, implementation, and utilization. Each was measured by using six indicators. The study results showed significant local communities and businesses/private involvement in managing and developing ecotourism. Meanwhile, the local government actors need to strengthen their involvement and response in ecotourism development. So far, the response has been relatively slow and waiting for the independent development of destinations that the community has carried out. Therefore, in the future, it is necessary to strengthen collaboration to ensure effective management of natural resources in ecotourism, which can be achieved through the support and cooperation of local government agencies, businesses/private, and the communities.
\end{abstract}

\section{A. INTRODUCTION}

The tourism sector has been chosen as an effective development option because it can offer a unique combination of features that provide opportunities to meet established guidelines for sustainable development (Wondirad et al., 2020:104). Sustainable tourism positively impacts the quality of life (Pothiban et al., 2020:1066); it benefits poverty reduction, infrastructure development, and social development (Yi et al., 2021:117). Tourism is a relatively clean and renewable alternative and has a symbiotic relationship with the ecosystem that lasts for life (Yuwono et al., 2021:129). In addition, tourism is defined as a "smokeless industry" and has

\footnotetext{
* Corresponding Author

Email : srimulyani@untidar.ac.id
} 
the value of utilizing natural (e.g., sun, sea, sand, wildlife), historical, social, and cultural resources.

Currently, various activities oriented to the public interest take place in a cross-sectoral network of diverse individuals and organizations. The topic of collaboration between interest actors in management and public services continues to shift to sectors with great potential and minimal damage, namely tourism (Suntikul et al., 2016:405). Collaborative governance is a collection of entities that work together to achieve common goals and generate public value (Ansell \& Gash, 2008:543). Tourism activities shape destination governance. One of them is ecotourism which examines the principles of tourism governance. Such governance at the institutional level is integrative and innovative (Rahmad Igarta \& Handayani, 2020:81), governance of economic performance, and social and environmental governance (Bichler \& Lösch, 2019:88).

Ecotourism is the practice of travelling to relatively less exploited natural destinations to appreciate natural settings, gain knowledge about wildlife, and enjoy the local culture in authentic settings while preserving the destination's environment (Rasoolimanesh \& Jaafar, 2016:76). Protected area authorities have widely facilitated ecotourism in many countries that promote tourism's sustainable development (Hendrix et al., 2021:528). Therefore, support from stakeholder actors is an essential part of balanced ecotourism because, if appropriately planned, ecotourism can provide significant economic benefits for residents (Y. E. Choi et al., 2021:104). Therefore, the World Ecotourism Summit (2002) covers five different criteria: nature-based products, minimum impact management, environmental education, contributions to conservation, and contributions to society. Ethics and sustainability have replaced 'minimum impact management' (Kalaitan et al., 2021:373; Rahmad Igarta \& Handayani, 2020:81).

A comprehensive ecotourism model includes sustainable characteristics that support environmental improvement, are global in scope, and socio-cultural and ecological dimensions (Yuwono et al., 2021:129). Ecotourism is often seen as part of the tourism industry's efforts to encourage sustainable tourism because it is expected to care about protecting the environment around tourist attractions and resisting the necessary changes in consumer behaviour and the development of hospitality infrastructure that can protect the environment (Y. E. Choi et al., 2021:104). Ecotourism is very important for local communities because it provides opportunities for communities to utilize their internal strengths and resources to become selfreliant, offering significant positive assistance to the economy and community welfare (Alfiandri et al., 2021:45). As an alternative way of accelerating the growth of ecotourism, help from stakeholders (government, national-international organizations, and businesses) regarding the friendliness of residents has aided in the development of ecotourism. On the other hand, a lack of human resources, production space, and raw material resources, combined with competition from industrial products, impede the advancement of ecotourism in Indonesian villages. As a result, several recommendations are made as guidance for developing ecotourism sustainability, specifically for Magelang Regency, which achievement from the benefits of ecotourism is overgrowing.

The purpose of this study is to analyze and elaborate the collaborative governance in sustainable ecotourism development in Magelang Regency, Central Java Province, Indonesia, and the obstacles experienced in the development of ecotourism. Strengthening the collaboration of three actors is needed in developing ecotourism because it comprehensively regulates natural destinations responsible for the sustainability of natural life, economic activity, and community welfare simultaneously (Ansell \& Gash, 2008:543). In developing countries such as Thanh Ha pottery village and Hoi An city, Vietnam shares geographical, social, and cultural characteristics with Indonesia. Ecotourism has been overgrown in that village due to the stakeholders' sense of responsibility and commitment to its development; this 
is done for the community's welfare and as a reference point for other villages (Pham Hong et al., 2021:3). In addition, this research focuses on collaborative governance on a cross-sectoral network of stakeholders organized to continue developing ecotourism, increasing the number of domestic and international visitors to Magelang Regency, advancing local community, social, and cultural and environmental goals of sustainable development. With this study, we combined the frameworks of collaborative processes such as building trust, commitment to the process (Ansell \& Gash, 2008:543), implementation, utilization (Kia, 2021:93) and the role of the community in the development of ecotourism destinations in Magelang Regency.

This research adds basic knowledge about the interrelationships between actors in ecotourism development, enriches the knowledge base for accelerating ecotourism development, minimizing conflicts, references to other areas with the same geographic structure and social features, and positive and wise public development governance. In addition, this research provides practical applications that can be applied in the short, medium and long term in the sustainability of ecotourism. Also, it becomes the basis of knowledge in solving problems and making policies related to improving institutional relations between institutions, actors, stakeholders, and society in the development of marine ecotourism.

\section{B. LITERATURE REVIEW \\ Sustainable Ecotourism: An Overview}

Sustainable world tourism is related to environmental values and cultural preservation (Yuwono et al., 2021:129). The purpose of cultural and ecological conservation is to minimize the damage that tends to occur during tourism activities, the damage that often happens during tourism activities, namely increased waste, environmental pollution, sanitation problems, and tourist ethics (Suntikul et al., 2016:405). It is recommended that sustainable tourism development be carried out by taking into account the nature, socio-cultural environment and prioritizing the welfare of the local community (Hall, 2019:1044). Furthermore, according to the United Nations World Tourism Organization (UNWTO), three basic principles must be met in implementing sustainable development: ecological sustainability, socio-cultural sustainability, and economic sustainability for the present and the future (UNWTO, 2017). The primary mission of sustainable tourism is to manage the tourism destination's resources so that economic, social, and human development objectives can be achieved by operating within the shared principles of preserving cultural and ecological integrity (Hall, 2019:1044). Financial goals have always been considered an essential aspect of development. Tourism offers a significant economic multiplier effect than other development options because it requires consumers (tourists) to travel to tourism sites (Bramwell et al., 2017:1). A large number of travellers impact the local economy by demanding a broad base of other products and services from the economic sector involving various suppliers and Medium Small Micro Enterprises (MSME) (Suntikul et al., 2016: 406).

The development of the sustainable tourism sector is currently heading towards a golden age. Many countries and regions are developing the concept of tourism in a new style; modern tourism destinations, digital tourism (e-tourism), tourist villages, halal tourism, sea tourism, water tourism, mountain tourism, cultural tourism, nature tourism, artificial tourism, craft tourism, religious tourism, and special interest tourism (Maturbongs, 2020:55). The involvement of local communities in resource management and their access to the generated income is emerging as essential in achieving the undisputed mandate to contribute to ecological sustainability (Wondirad et al., 2020:78). Nonetheless, there are cases where external interests, especially at the national or global level, can marginalize the needs of local communities (Y. E. Choi et al., 2021:104). Apart from the case of greenwashing in ecotourism, it is often presented as a clear departure from mass tourism, being positioned in alternative forms of 
tourism. Ecotourism continues to be the most promoted form of alternative tourism due to its apparent link to triple-bottom-line sustainable development (Kalaitan et al., 2021:373).

The principle of community-based Ecotourism (CBE) ensures the interests of local communities by promoting local management, local ownership and environmental education (Fyall et al., 2012:10). Further, it puts the needs of local communities at the forefront, a participatory approach to decision-making, access to resources, equitable distribution of economic benefits, and local entrepreneurship and diversification (Presenza et al., 2015:479). The challenge of ecotourism lies in ensuring an adequate interpretation of environmental, cultural and resource management values across all stakeholders involved in its development (Rasoolimanesh \& Jaafar, 2016:76). Indirectly, ecotourism can contribute to the challenges faced by local communities, such as the impact of unplanned growth, limited job opportunities, revenue uncertainty and leakage; the proliferation of crime; erosion of social relations; nonlocal participation; and wildlife damage (Mulyani et al., 2020:1). Several researchers also reveal critical factors that hinder ecotourism's sustainability. There are 1) limited access to tourism markets, 2) lack of commercial viability for local products, 3) incoherent marketing strategy, 4) marginalization of local wisdom, 5) lack of appropriate intergovernmental policies, and 6) planning and managerial incompetence (Presenza et al., 2015:479).

\section{Collaborative Governance in Ecotourism}

The tourism sector is one of the various sectors that implement collaborative governance to accelerate sustainable tourism development ( $\mathrm{Lim}, 2019: 73)$. Governance in tourism aims to organize and coordinate destinations, coordinate local stakeholders to design and develop destinations (Presenza et al., 2015:479), encourage valuable forms of commitment, synergy, and collaboration between public - private actors, and assist policy makers in implementing sustainable development (Lim, 2019:73). Governance is about structures and processes and aims to understand the how and why of different components such as institutional design, personal relationships, and shared networks. However, tourism governance often focuses on business and government interests rather than multiple stakeholders (Ansell \& Gash, 2008:543; Suntikul et al., 2016:405). Previous research has shown that "good governance" includes several dimensions such as participation, legitimacy, transparency, and efficiency (Bichler \& Lösch, 2019:1).

Collaboration between actors is essential for good governance because tourism represents a fragmented industry with a wide variety of actors working together to provide tourism services (Jamal \& Budke, 2020:181). In this context, managing relationships with stakeholders become imperative to ensure legitimacy and acceptance (Hall, 2019:1044; UNWTO, 2017). However, these relationships can be costly and time-consuming when broad and varied barriers to engaging with stakeholders. To assess these drivers and barriers, we explain further the processes that underlie collaborative governance, especially in ecotourism which is evaluated from development planning, implementation (Nunkoo \& Gursoy, 2012:243), and utilization ecotourism by the value of sustainable development (UNWTO, 2017).

Several sources in the literature explanation above have been included in one complete sentence to shorten the answer and only take the essence of the reading. This study differs from previous research because it provides a more detailed description of each actor's involvement in developing the Magelang tourism sector. This can serve as a model for other regions interested in accelerating the development of the tourism sector, particularly in the development of ecotourism. Stakeholders require commitment, transparency, and fair policies and allow the community to develop its regional potential. The case study was conducted in Magelang Regency because it is a super-priority area (KSP) designated by the central government to accelerate the development of the tourism sector. It can be used as a reference 
and role model for other regions with great potential in Magelang Regency. The central government is fully committed to making the area being a top priority in developing the tourism sector (Publik, 2021). The Ministry of Tourism and Creative Economy (in the future referred to as KEMENPAREKRAF) and the Ministry of Transportation (in the future referred to as KEMENHUB) (Ra, 2021) and the Ministry of Villages, Development of Disadvantaged Regions, and Transmigration (in the future referred as KEMENDesa). The Magelang Regency Government develops tourist destinations to support the Super Priority Tourism area (Wibisono, 2021). This super-priority area is included in Presidential Regulation (in the future referred to as Perpres) Number 79 of 2019 concerning the Acceleration of Economic Development in Priority Areas.

\begin{tabular}{|c|c|c|c|c|c|}
\hline (1) & (2) & (3) & (4) & (5) & \multirow{4}{*}{$\begin{array}{c} \\
\vdots \\
\text { Periodic } \\
\text { Update } \\
\vdots\end{array}$} \\
\hline \multirow{3}{*}{ 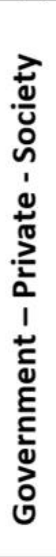 } & Starting Conditions & Planning & \multirow{3}{*}{$\begin{array}{l}\text { 1. Characteristics of } \\
\text { Implementing; } \\
\text { 2. Attitudes of } \\
\text { implementers; } \\
\text { 3. Communication } \\
\text { between related } \\
\text { organizations and } \\
\text { implementation } \\
\text { activities; } \\
\text { 4. Social, economic and } \\
\text { political environment. }\end{array}$} & $\begin{array}{l}\text { - Power Resource } \\
\text { - Knowledge-Sustainability } \\
\text { - Problem } \\
\text { - Accessibility } \\
\text { - Promotion } \\
\text { - Funding }\end{array}$ & \\
\hline & Collaborative Process & Implementing & & $\begin{array}{l}\text { - Trust Building } \\
\text { - Face-to-Face Dialogue } \\
\text { - Commitment } \\
\text { - Shared Under-Standing } \\
\text { - Maintaining: Infrastructure-Objects } \\
\text { - Ecotourism } \\
\text { - Sustainable Concept }\end{array}$ & \\
\hline & Outcomes & Utilization & & $\begin{array}{l}\text { - Direct Benefits } \\
\text { - Indirect Benefits } \\
\text { - Local Labour } \\
\text { - Social benefits }\end{array}$ & \\
\hline
\end{tabular}

Source: Adopted from (Ansell \& Gash, 2008:543; Jaafar et al., 2015:17; Kia, 2021:93; Nunkoo \& Gursoy, 2012:243)

Figure 1. Theoretical Framework - Collaboration of Ecotourism Governance

\section{METHOD}

A qualitative-quantitative exploratory explains more of the fundamental phenomena in sustainable development. The aim is to form a new concept that is friendly to the environment and improves people's welfare, increased economy, and peaceful social activities (Neuman, 2014; Purnomo, Fathani, et al., 2021:477). The mixed-method explorative approach is considered helpful in conducting research, is more comprehensive, and describes the findings (Alfiandri et al., 2021:45). In addition, it makes it easier for readers to understand the complexities of the ecotourism network (Neuman, 2014). Magelang Regency is selected as a locus based on data increase in ecotourism development which has continued to increase since 2015-2020 as many as 47 destinations. The increase in ecotourism destinations is supported by multilevel policies from local and central governments to accelerate sustainable tourism development (Table 1). However, there are still weaknesses, namely the limited involvement of local communities (Pham Hong et al., 2021:1).

Research data were collected using in-depth interviews with eight local government staffs, 22 ecotourism managers, and 42 communities around the destination. The questions were designed to address to geographic information and responses to planning, implementation, and utilization variables using 16 indicators. Questions were measured on a composite and reflective basis specific to ecotourism sustainability. In this study, collaboration governance is defined as a cooperation between the regency, sub-regency, village-level employees, developers (private sector), non-government organizations (NGOs), environmental activists, and local communities. The results of the interviews were analyzed using the NVIVO12+ 
software to see the value of the interval to create a structural equation model. Andrew EdwardsJones suggests this mode of analysis in exploratory study research (Edwards-Jones, 2014:193). In most cases, the equation with the highest number of independent variables is considered to determine the minimum number of observations required to detect the effect reliably (Ghozali, 2014:2).

Table 1. Figures for Selected Stakeholders and Respondents

\begin{tabular}{llrr}
\hline No & Respondents Group & Members of Boards & \multicolumn{1}{c}{ Total } \\
\hline 1 & Magelang Regency & 8 & $11.2 \%$ \\
2 & EcoTourism Manager & 22 & $30.5 \%$ \\
3 & Local Communities & 42 & $58.3 \%$ \\
\hline & Total & $\mathbf{7 2}$ & $\mathbf{1 0 0 \%}$ \\
\hline
\end{tabular}

\section{RESULT AND DISCUSSION}

\section{Stakeholder Involvement in Ecotourism}

The involvement of stakeholders in the development of the ecotourism sector in Magelang Regency is seen from 3 measurement points: planning, implementing and utilizing ecotourism (Rasoolimanesh \& Jaafar, 2016:76). The measurement points have their respective indicators to see in more detail the role of each stakeholder in developing ecotourism in the Magelang Regency. The local government's involvement in ecotourism development is based on various regulations that focus on sustainable development, rules from the national to local levels supporting each region to utilize/manage their area in the development of the tourism sector (Table 2).

Table 2. Regulations Sustainable Tourism Development

\begin{tabular}{|c|c|c|c|}
\hline No & Regulation & Scale & Concern \\
\hline 1 & Law Number 5 of 1990 & National & $\begin{array}{l}\text { Conservation of Biodiversity and Its } \\
\text { Ecosystems }\end{array}$ \\
\hline 2 & $\begin{array}{l}\text { Minister of Home Affairs Regulation } \\
\text { Number } 33 \text { of } 2009\end{array}$ & National & $\begin{array}{l}\text { Guidelines for Ecotourism Development in } \\
\text { the Regions }\end{array}$ \\
\hline 3 & Law Number 9 of 2010 & National & Tourism \\
\hline 4 & $\begin{array}{l}\text { Regional Regulation Number } 4 \text { of } \\
2015\end{array}$ & Local & $\begin{array}{l}\text { Master Plan for Tourism Development of } \\
\text { Magelang Regency 2014-2034 }\end{array}$ \\
\hline 5 & $\begin{array}{l}\text { Minister of Tourism Regulation } \\
\text { Number } 14 \text { of } 2016\end{array}$ & National & $\begin{array}{l}\text { Guidelines for Sustainable Tourism } \\
\text { Destinations }\end{array}$ \\
\hline 6 & $\begin{array}{l}\text { Regional Regulation Number } 9 \text { of } \\
2018\end{array}$ & Local & $\begin{array}{l}\text { Tourism Business Operators in Magelang } \\
\text { Regency }\end{array}$ \\
\hline 7 & $\begin{array}{l}\text { Central Java Provincial Regulation } \\
\text { Number } 2 \text { of } 2019\end{array}$ & Regional & $\begin{array}{l}\text { Empowerment of Tourism Villages in Central } \\
\text { Java Province. }\end{array}$ \\
\hline
\end{tabular}

Table 1 demonstrates how the involvement of local government actors has begun to be structured to accelerate the national development of the tourism sector. The primary support from the central government is by establishing several major regulations for equality of development. Each region is given the freedom to make regulations in developing their respective potentials based on their field conditions. The second stakeholder from the private sector is the travel agency and lodging business. These two stakeholders have an intense relationship with ecotourism. Utilizing the mountainous geographical landscape with natural atmosphere, environment, and cold weather, these stakeholders prioritize the advancement of ecotourism in Magelang Regency. Although they do not have formal powers obtained from the local government, these two stakeholders are permitted to promote and provide accommodation for tourists. The legitimacy is accepted because the local government allows these two stakeholders to encourage and provide accommodation for tourists. 
Furthermore, local communities and small business groups are tourism service providers directly involved in providing souvenirs, tour guides, tourist attractions, and restaurants. Local communities can provide services to tourists because they get permission from the local government to carry out their activities. As a basis for their legitimacy, they have licenses for agricultural, natural, river, mountain tourism attractions which are the main attraction for tourists to introduce special interest tourism in the form of adventure around the destination. The license obtained is in the form of a certificate of appropriate use to establish attractions and tourists assistance. This certificate is obtained before opening tourist destinations through government-provided training, development, and primary education (Andy, 2020). The three primary stakeholders are groups directly related to ecotourism activities.

From this explanation, ecotourism stakeholders, including the local government, the private sector, and the community, are involved in implementing and providing tourist services (Bichler, 2021:100). Stakeholders have direct involvement in providing services to tourists, directing, and providing facilitation to facilitate services. In addition, from the various limitations possessed by these stakeholders, it is possible to carry out collaborative relationships so that synergies occur between the three pillars. This cooperative relationship can be realized in various forms, and from this, diversity can be identified as the essential collaborative activity (Bichler \& Lösch, 2019:1). From the multiple limitations that stakeholders have, the phenomenon of collaboration that emerges from this collaborative relationship can be described as a complex engagement relationship (Renn, 2015:8). By the concept that has been stated above, the complexity of this relationship is the main characteristic of governance.

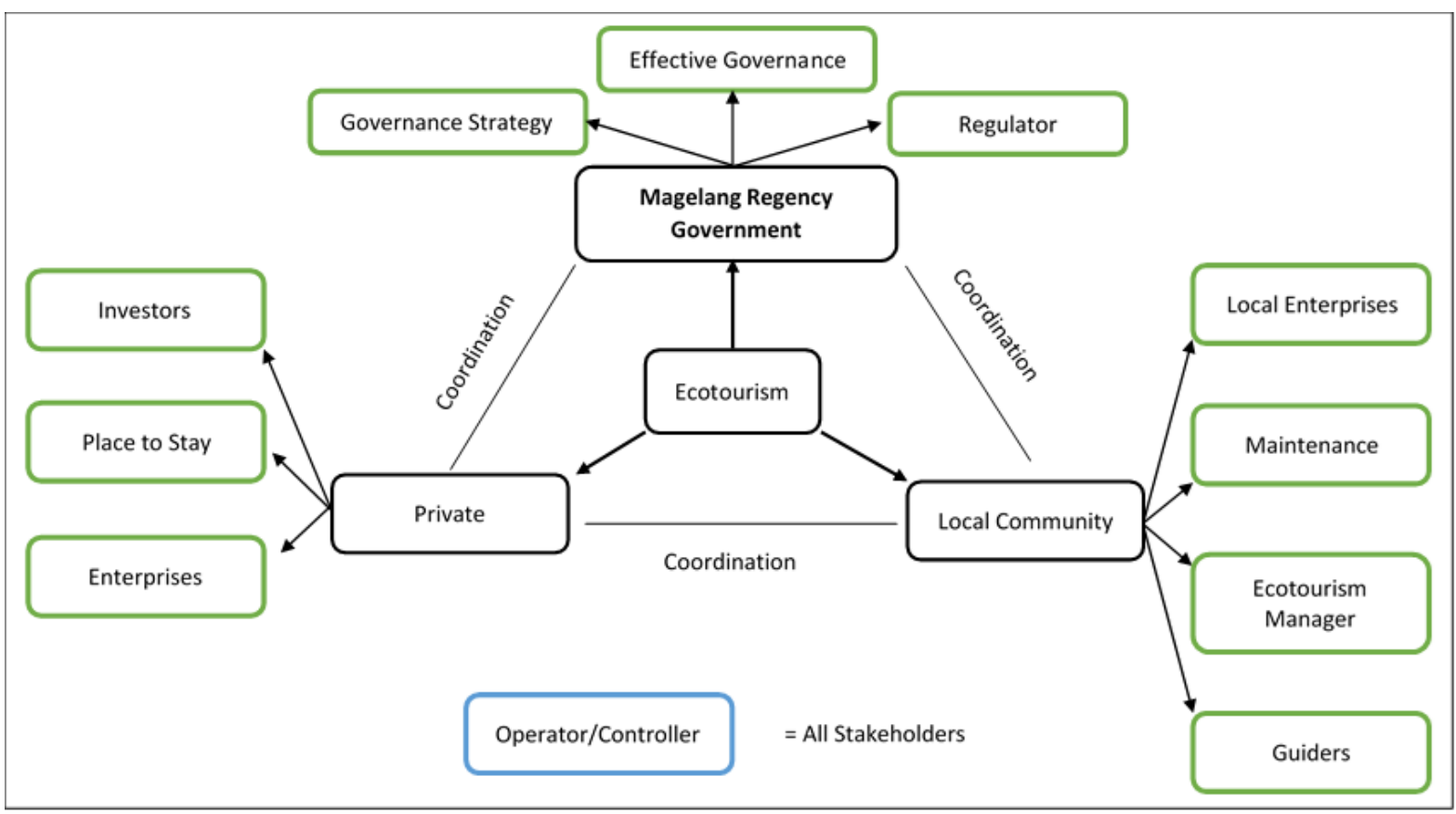

Source: Author Analysis Based on In-depth interview

Figure 2. Stakeholder Involvement in Ecotourism (Planning, Implementing, Utilizations) in Magelang Regency

Figure 2 describes the involvement between stakeholders which looks so complex. Therefore ecotourism destinations in Magelang Regency continue to increase significantly in 
5 years (2015-2020), namely 47 ecotourism destinations. This collaboration framework also facilitates the description and subsequent analysis, considering that stakeholders can carry out collaborative transformations. The concept stated earlier is that stakeholders are the main drivers of collaboration.

\section{The Values Involvement of Each Actors}

From the field findings, it can be seen that the involvement of various stakeholders between the local government, the private sector and the community forms a triangular relationship pattern that focuses on working together in developing sustainable ecotourism by the vision and mission of each actor. Furthermore, from this finding, the researcher conducted a more detailed study to find values on the role and contribution of each actor in the development of sustainable ecotourism in the Magelang regency. As shown in Figure 1, the local government plays an essential role in creating new strategies, regulations, and governance to support the sustainability of the tourism sector, especially in creating sustainable ecotourism. The researcher conducted an in-depth analysis to find the value of the involvement of local government actors in the development of ecotourism in the Magelang Regency (Figure 2).

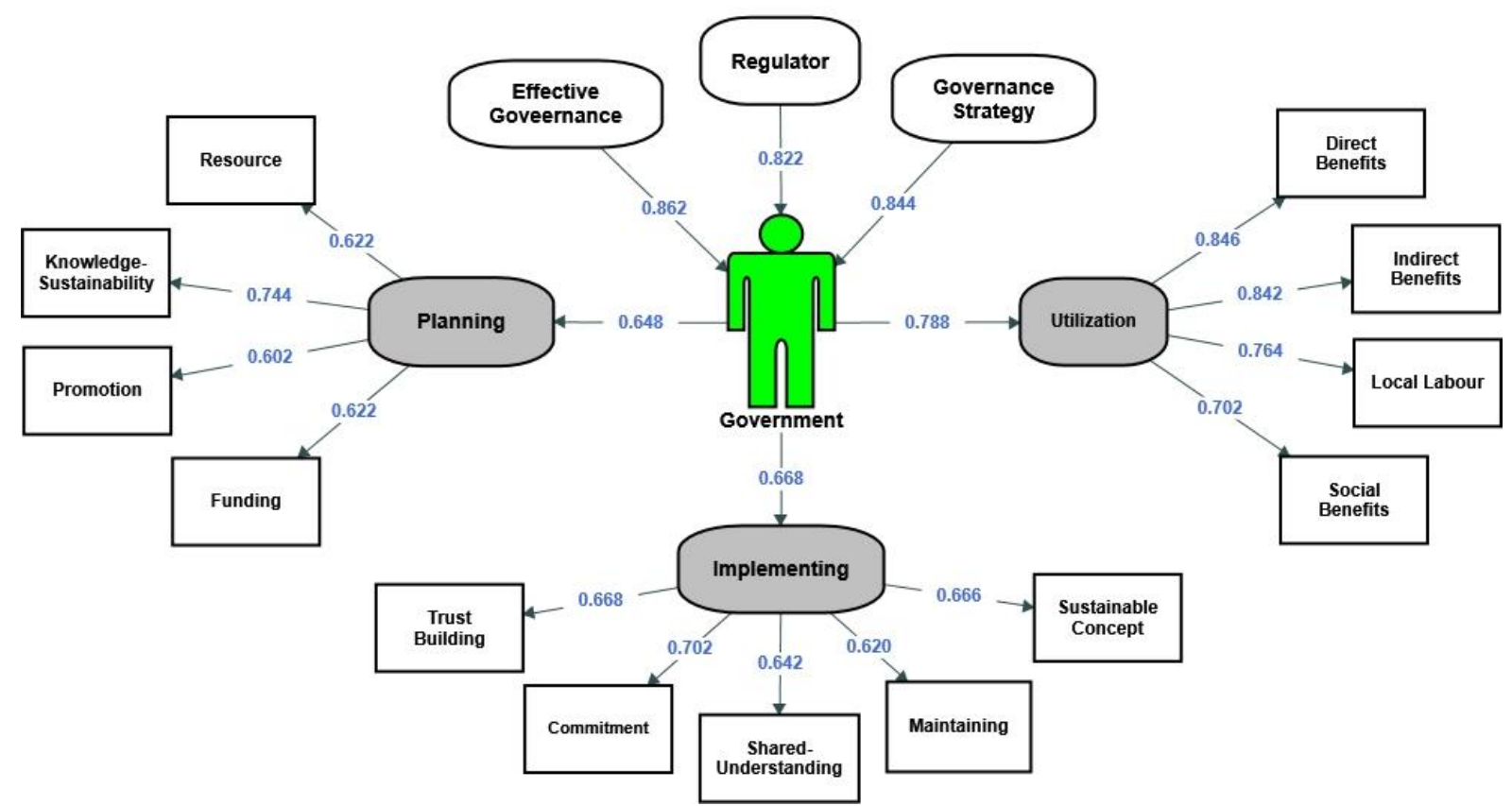

Source: Author analysis based on In-depth interview

Figure 3. The Value's Involvement of Government

Figure 3 shows the analysis results carried out based on interviews, thus showing the value of local government involvement in ecotourism development in the Magelang Regency. As a substantial actor in creating regulations or as a regulator $(0.822),(0.648)$, implementation (0.668), and utilization (0.788). First, planning for the development of ecotourism in Magelang Regency, the local government is slow in planning ecotourism (0.648). This is because the local government waits for the direct role of private actors and local communities to develop independently. After seeing a significant development and having great potentials, the government efforts to get involved and take over the destination because it doesn't want the regional assets to be managed without local government control. This can be seen from the 
creation of regulations, suitable governance arrangements, and efforts to develop strategies that the private sector and the community have implemented.

On the other hand, unlike Than Ha village in Vietnam, the local government leads actor and initiator in the development of ecotourism (Pham Hong et al., 2021). In addition, they also provide with funds, seek relationships in accelerating the development of ecotourism. Thailand (Koh Tao and Chiang Mai) and Laos (Phou Khao) also do the same thing; the local government is responsible for the welfare of its people and supports the efforts to develop ecotourism (Landy et al., 2021; Tetiwat et al., 2019).

Second, the local government's involvement in implementation (0.668) is also relatively low compared to other actors. This is caused by minimal planning that affects other indicators, namely trust in the government (0.668), commitment (0.703), sharing (0.620), and maintenance (0.620). Third, in terms of utilization, it is different from ecotourism activities which get a high score compared to other indicators, namely 0.788 . Although the local government actors get minimal value in planning and implementation, the local government tries to bring significant benefits from ecotourism activities. The advantage of taxes are indirect income in local revenue (PAD), reducing unemployment, and getting social benefits, namely branding-icon and attracting tourists to visit. This is similar to what the Cambodian government has done, aggressively pursuing tourism taxes without developing the tourism sector (Kibria et al., 2021). Contrary to the literature review, their role is needed, especially in encouraging development and not just looking for profit.

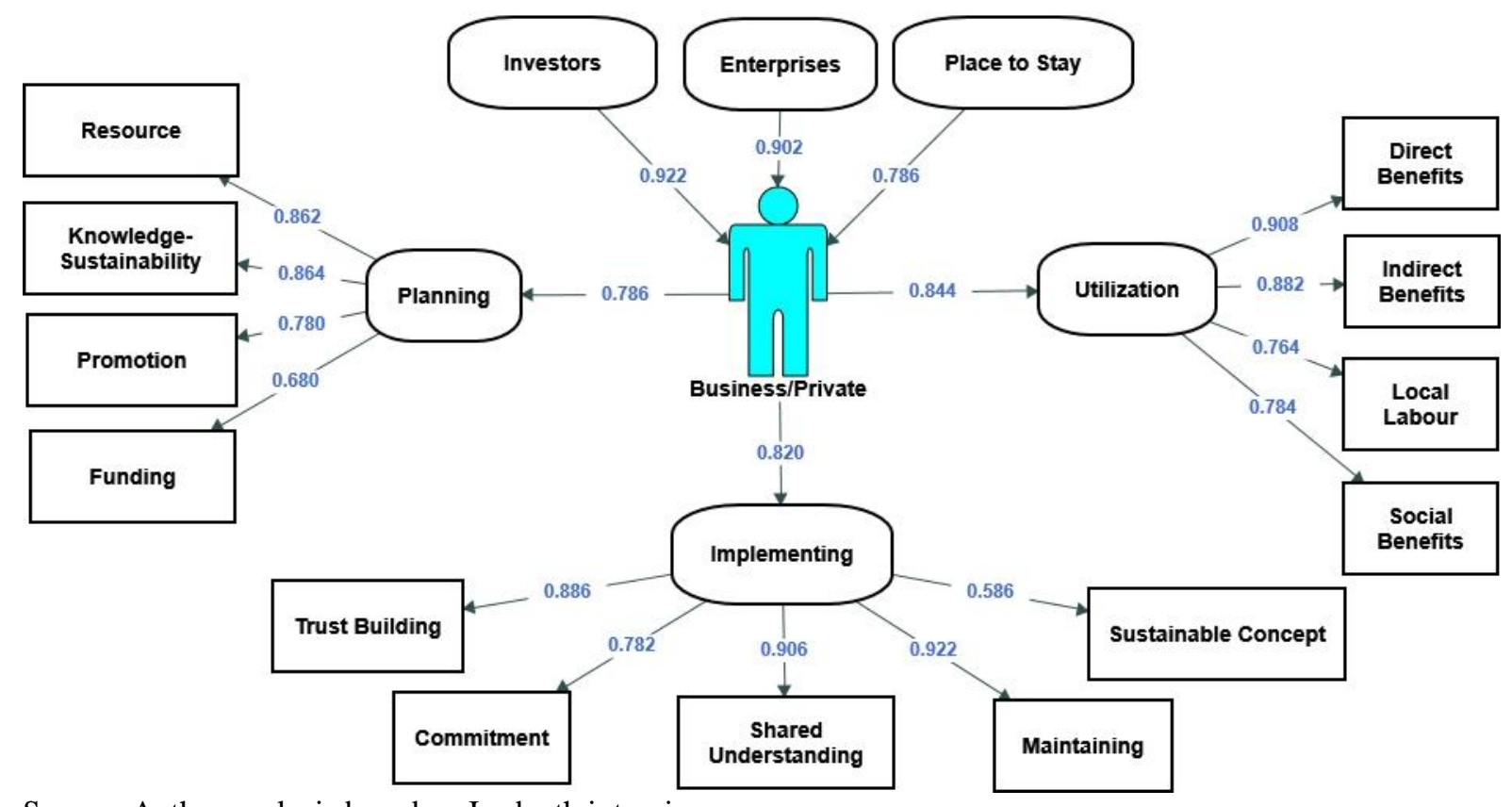

Source: Author analysis based on In-depth interview

Figure 4. The Value's Involvement of Business/Private

Figure 4 shows the analysis results showing the value of the involvement of business/private actors in the development of ecotourism in the Magelang Regency. As a substantial actor in developing ecotourism destinations that can increase investment opportunities (0.922), ecotourism businesses (0.902) and can increase regional physical development (0.786) to convince tourists to visit and enjoy ecotourism destinations. In terms of investment and physical development of the region, the presence of business/private actors is very rapid, so that there are many varied class size clusters in facilitating ecotourism tourists (Alfiandri et al., 2021; Garrod et al., 2012). First, planning (0.786) carried out by 
business/private actors gets a higher value than the local government actors; this can be seen from the seriousness in finding reliable natural resources and human resources. Success in finding these resources makes it easier for businesses and privates to promote ecotourism on social media and online media to attract the attention of tourists. Second, in terms of implementing business/private actors, they have a high score. This value is caused by the actor's shared understanding, controlling and maintaining destinations. This can increase the trust given by the community to collaborate in managing ecotourism. Third, the high values obtained by the previous indicators significantly affect the utilization obtained by business/private actors, including direct benefits, indirect benefits, employment opportunities, and extensive social interaction in the community.

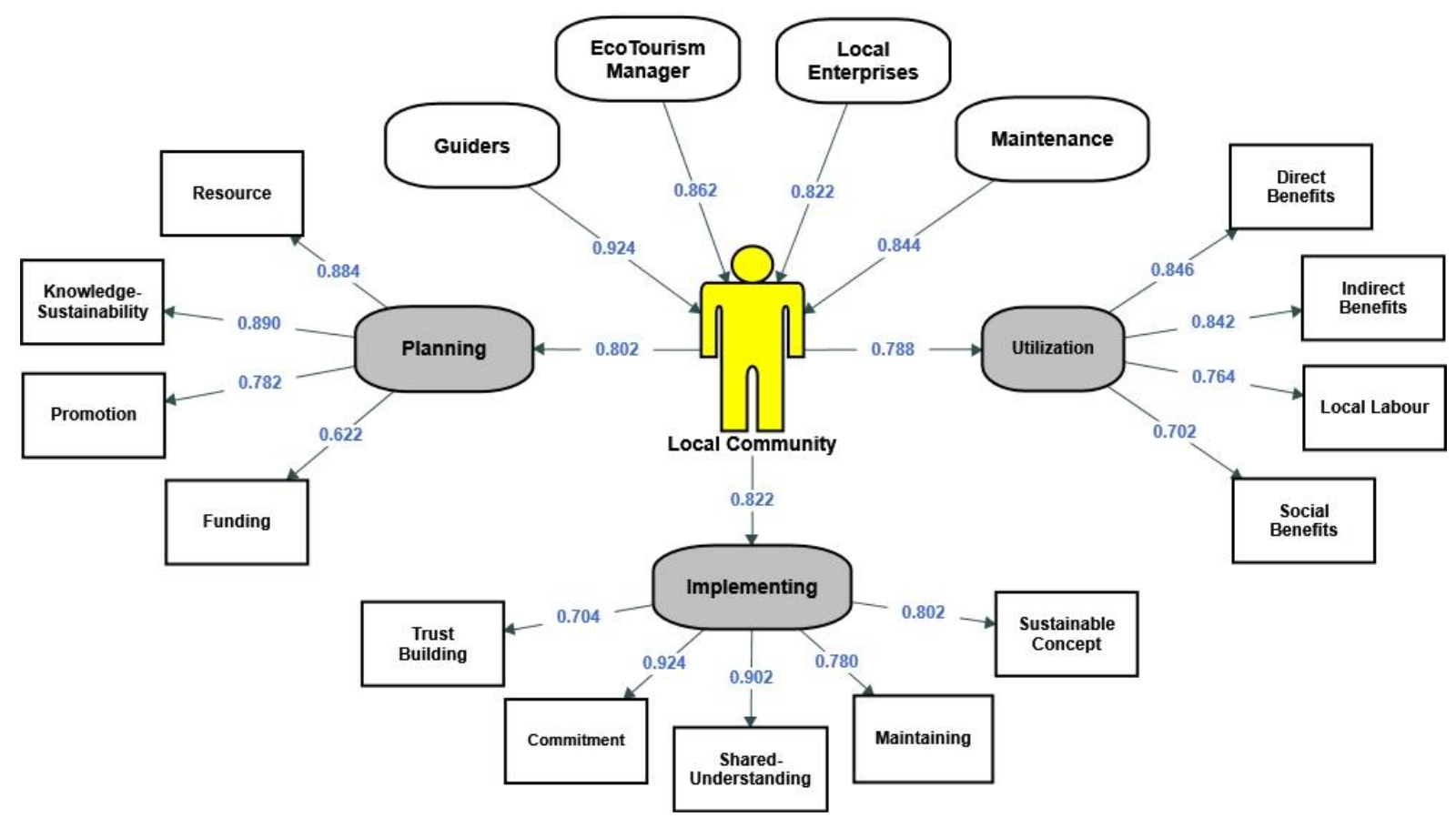

Source: Author analysis based on In-depth interview

Figure 5. The Value's Involvement of Local Community

Figure 5 shows the analysis results based on interviews, thus showing the value of local community involvement in ecotourism development in the Magelang Regency. As the leading actor in developing the potential of significant natural resources in ecotourism activities, the local communities play an essential role in maintaining nature by accompanying every ecotourism activity (0.924). This involvement brings the community closer to every tourist to provide a sense of security, comfort, and confidence in carrying out ecotourism activities (0.862). In addition, integrated management and prioritizing the concept of a sustainable environment (Eshun \& Tichaawa, 2020; Kalaitan et al., 2021) provides the community with great opportunities in creating businesses to support tourism activities, such as giving local artworks, local food, and solid social interaction with tourists especially the development of tourism (Y. E. Choi et al., 2021). The very rapid ecotourism cannot be separated from the involvement of local communities in carrying out maintenance to support the sustainable development of ecotourism in the Magelang Regency (0.844).

First, the planning for the development of ecotourism in Magelang Regency is planned by the local community to support the potential of local natural resources that have many benefits if managed wisely and correctly (0.802). By relying on the possibility of local communities who master geographical instruments and natural conditions and upholding the concept of 
environmental sustainability, ecotourism is increasingly enjoyed by tourists (Anista \& Marsigit, 2020; Pamungkas et al., 2021). In conducting marketing and promotion, information dissemination is carried out in stages, starting from the interaction between local communities, and gradually spreading to all communities in Magelang Regency and Central Java Province (0.782). The rapid development has convinced local communities to conduct local media, online media news, and social media networks to reach a broader tourism market. It can gradually attract national investors, resulting in the significant development of ecotourism (Lim, 2019; Nunkoo, 2017).

The second is implementation (0.822); the local community has a higher value than other actors. This is inseparable from the local community's initiative to utilize natural resources independently because it is far from the reach of the government, by carrying out a firm commitment, building trust between communities, prioritizing the environment and natural sustainability concept, and following shared understanding, empowerment, and tourism training. The local community is open to receiving input, suggestions, ideas, new concepts, empowerment, training, and new knowledge from national tourism experts (Clayton \& Boxill, 2012). This is inseparable from the desire of local communities to utilize natural resources without destroying nature (Kuncoro et al., 2019).

The third is utilization, although the planning and implementation of local community actors get a high value. In terms of direct benefits, the community can feel an increase in economic activity, the standard of living, and community consumption from the ecotourism activity. In the sub indirect benefits, the local community can enjoy developing knowledge for ecotourism development models in the future; these ideas are obtained from the interactionfree social activities or shared understanding with tourists, academics, and scientists who are enjoying ecotourism activities. In employment, local communities reduce unemployment and benefit from branding icon. This makes it easier for local people to promote their area to attract tourists to visit and interact socially for free. The participation of the local community is essential for the success of the tourism industry because it is considered one of the products of tourism, and their input in the tourism development decision-making process should be the focal point (Damanik \& Yusuf, 2021; Zolfani et al., 2015).

The stakeholders involved in ecotourism are pretty diverse, and between these stakeholders, there has been a collaborative relationship indicated by various activities in the form of tourism services (Fyall et al., 2012). Through the Department of Tourism, Youth, and Sports, the local government has a relationship with the private sector to pay taxes and levies every year. In addition, the village government with private parties and the community often conducts coaching and strengthening local groups by bringing in various charitable institutions to improve tourist services. Local groups fostered multiple activities, namely community service programs from multiple agencies and institutions in Yogyakarta, Central Java, and Jakarta. It is known that there is a phenomenon of collaboration between the local government and the private sector. The private sector, consist of travel and lodging agencies, performs its duties to provide added value to tourism. It becomes an alternative to regional income by paying regional taxes and levies. As a form of reciprocity, the local government provides facilitation to stimulate the tourism industry with various facilities, both in access to obtain information and permits.

As for the relationship pattern between the local government and the community, community groups that provide tourism services and services have a work background as farmers. The local government should improve its tourism service providers' capabilities and competencies and open access to various mentoring programs from universities and nongovernmental organizations. Furthermore, from the pattern of relationships between the private sector and the community, it is known that the phenomenon of the relationship that occurs is 
transactional and economical. Communities around tourism objects feel that they have extensive information and networks on developing ecotourism to provide excellent and sustainable benefits.

In organizing the facts related to the barriers that affect ecotourism development in developing countries, three obstacles are faced in managing tourism: operational, structural, and cultural borders (UNWTO, 2017). The formulation and implementation of public participation in centralising the tourism sector's public administration require the government's political, administrative and financial power. However, planning is a centralized activity (Bichler \& Lösch, 2019:1). This has resulted in the limited influence of the community in the planning and implementation process, so centralization hinders community participation in the planning process (T. Choi \& Robertson, 2014:495). It does increase the range of vertical relations between policy-makers and the public. The highly fragmented tourism industry's lack of coordination and cohesion has become a 'well-known problem' for tourism professionals (Robertson, 2011:279). Therefore, it is necessary to develop knowledge and more integrity in enjoying ecotourism activities.

Moreover, ecotourism activities have the main issue and function, namely the environmental part. This function aims to prevent or minimize tourism's negative impacts and consequences. This goal is achieved through strict regulation of influence, determination of acceptable norms for recreational loads, zoning of areas, planning of tourist routes, and arrangement of infrastructure objects to achieve sustainable ecotourism development.

\section{E. CONCLUSION}

The current study aims to assess the original contribution of local government-privatelocal community collaborative governance in sustainable ecotourism development and how these actors manage the available resources into eco-friendly tourism destinations and provide significant benefits to local communities without harming the environment. We assessed each actor's primary involvement using the three criteria and 16 indicators in the study. In the context of planning and implementation, the participation of local and private communities is very significant because the creation of ecotourism destinations begins with public awareness to improve the local economy by utilizing natural resources. Then it is supported by the involvement of business/private actors in funding, conducting shared understanding with external parties so that the empowerment and development of local communities continue to increase, and routinely controlling and maintaining ecotourism. In addition, local communities have human resources that have homogeneous characteristics that can increase cooperation in developing ecotourism destinations.

The utilization of the ecotourism destination is quite felt by the actors concerned, just as the local government has other income to support local revenue (PAD) through taxes and billboards and reduce unemployment and poverty in the community. For business/private, the benefits obtained are also quite significant, investment opportunities are opened, and tourism services businesses are increasingly excited to continue improving sustainable ecotourism destinations. Furthermore, the benefits of ecotourism for local communities are numerous, namely increasing local economic activity so that the poverty rate decreases, reducing unemployment, and increasing the ability and potential of local communities to compete with other regions in the development of ecotourism. The results show the complexity of collaborative governance in managing sustainable ecotourism development in the Magelang Regency. The pursuit of sustainable ecotourism governance supported by the organization and connectedness of strong actors can make planning, implementation, and utilization instruments more focused and structured. The point that needs to be continuously observed and concentrated in the future is increasing local government actors' response and intense 
involvement in achieving sustainable ecotourism. The government only comes and helps when existing destinations show significant developments. Therefore, future research needs to emphasise on the local government's contribution to be more active in responding, managing, and utilizing regional potentials to create community welfare.

\section{Contributorship}

Conceptualization: SM, RDPA and DNW; methodology: DNW; software: RDPA and DNW; validation: SM; formal analysis, DNW: writing original draft preparation: SM, RPA, DNW; writing review and editing: SM and DNW; visualization: RDPA. All authors have read and agreed to the published version of the manuscript.

\section{REFERENCES}

Alfiandri, A., Prasojo, E., \& Salomo, R. V. (2021). Collaboration of Marine Ecotourism in Riau Islands Province Towards Sustainable Tourism. Advances in Social Sciences Research Journal, 8(3), 45-60. https://doi.org/10.14738/assrj.84.9798

Andy, H. (2020). Tahapan Merintis dan Mengembangkan Desa Wisata. Eticon. https://eticon.co.id/tahap-merintis-desa-wisata/

Anista, R., \& Marsigit, M. (2020). Direct identification of Borobudur temple artefacts for learning flat shapes concepts. Journal of Physics: Conference Series, 1613(1), 0-7. https://doi.org/10.1088/1742-6596/1613/1/012021

Ansell, C., \& Gash, A. (2008). Collaborative governance in theory and practice. Journal of Public Administration Research and Theory, 18(4), 543-571. https://doi.org/10.1093/jopart/mum032

Bichler, B. F. (2021). Designing tourism governance: The role of local residents. Journal of Destination Marketing \& Management, 19, 100-389. https://doi.org/10.1016/j.jdmm.2019.100389

Bichler, B. F., \& Lösch, M. (2019). Collaborative governance in tourism: Empirical insights into a community-oriented destination. Sustainability (Switzerland), 11(23), 1-19. https://doi.org/10.3390/su11236673

Bramwell, B., Higham, J., Lane, B., \& Miller, G. (2017). 25 years of Sustainable Tourism and the Journal of Sustainable Tourism. Journal of Sustainable Tourism, 25(1), 1-9.

Choi, T., \& Robertson, P. J. (2014). Deliberation and decision in collaborative governance: A simulation of approaches to mitigate power imbalance. Journal of Public Administration Research and Theory, 24(2), 495-518. https://doi.org/10.1093/jopart/mut003

Choi, Y. E., Oh, C.-O., \& Chon, J. (2021). Applying the resilience principles for sustainable ecotourism development: A case study of the Nakdong Estuary, South Korea. Tourism Management, 83, 104-237. https://doi.org/10.1016/j.tourman.2020.104237

Clayton, A., \& Boxill, I. (2012). Worldwide Hospitality and Tourism Themes. Tourism Themes Iss, 4(4), 98-100. http://dx.doi.org/10.1108/17554211211198598\%5Cnhttp://

Damanik, J., \& Yusuf, M. (2021). Effects of perceived value, expectation, visitor management, and visitor satisfaction on revisit intention to Borobudur Temple, Indonesia. Journal of Heritage Tourism, O(0), 1-16. https://doi.org/10.1080/1743873X.2021.1950164

Edwards-Jones, A. (2014). Qualitative data analysis with NVIVO. Journal of Education for Teaching, 40(2), 193-195. https://doi.org/10.1080/02607476.2013.866724

Eshun, G., \& Tichaawa, T. M. (2020). Towards sustainable ecotourism development in Ghana: Contributions of the local communities. Tourism, 68(3), 261-277. https://doi.org/10.37741/T.68.3.2

Fyall, A., Garrod, B., \& Wang, Y. (2012). Destination collaboration: A critical review of theoretical approaches to a multi-dimensional phenomenon. Journal of Destination 
Marketing and Management, 1(1-2), 10-26. https://doi.org/10.1016/j.jdmm.2012.10.002 Garrod, B., Fyall, A., Leask, A., \& Reid, E. (2012). Engaging residents as stakeholders of the visitor attraction. Tourism Management, 33(5), 1159-1173. https://doi.org/10.1016/j.tourman.2011.11.014

Ghozali, I. (2014). Structural Equation Modeling: Metode Alternatif dengan Partial Least Squares (PLS) (4th ed.). Badan Penerbit Universitas Diponegoro.

Hall, C. M. (2019). Constructing sustainable tourism development: The 2030 agenda and the managerial ecology of sustainable tourism. Journal of Sustainable Tourism, 27(7), 10441060. https://doi.org/10.1080/09669582.2018.1560456

Hendrix, T., Isnasari, Y., Berliandaldo, M., \& Kholiyah, S. (2021). Implementasi Kebijakan Perlindungan Kekayaan Intelektual Terhadap Efektivitas Produk Penelitian dan Pengembangan. Jurnal Borneo Administrator, 17(1), 41-64. https://doi.org/10.24258/jba.v17i1.754

Jamal, T., \& Budke, C. (2020). Tourism in a world with pandemics: local-global responsibility and action. Journal of Tourism Futures, 6(2), 181-188. https://doi.org/10.1108/JTF-022020-0014

Jaafar, M., Rasoolimanesh, S. M., \& Lonik, K. A. T. (2015). Tourism growth and entrepreneurship: Empirical analysis of development of rural highlands. Tourism Management Perspectives, 14, 17-24. https://doi.org/10.1016/j.tmp.2015.02.001

Kalaitan, T. ., Stybel, V. ., Gutyj, B. ., Hrymak, O. Y., Kushnir, L. ., Yaroshevych, N. ., Vovk, M. ., \& Kindrat, O. . (2021). Ecotourism and sustainable development. Prospects for Ukraine. Ukrainian Journal of Ecology, 11(1), 373-383. https://doi.org/10.15421/2021_55

Kia, Z. (2021). Ecotourism in Indonesia: Local Community Involvement and The Affecting Factors. Journal of Governance and Public Policy, 8(2), 93-105. https://doi.org/10.18196/jgpp.v8i2.10789

Kibria, A. S., Behie, A., Costanza, R., Groves, C., \& Farrell, T. (2021). Potentials of community-based-ecotourism to improve human wellbeing in Cambodia: an application of millennium ecosystem assessment framework. International Journal of Sustainable Development \& World Ecology, 28(5), 461-472. https://doi.org/10.1080/13504509.2020.1855606

Kuncoro, B., Nugraha, J. T., \& Ahsani, R. D. P. (2019). Pengembangan Potensi Destinasi Desa Wisata Menggunakan Indeks Pembangunan Desa di balesari Kecamatan Windusari Kabupaten Magelang. Jurnal Ilmu Administrasi Negara ASIAN (Asosiasi Ilmuwan Administrasi Negara), 7(2).

Landy, F., Chand, R., Déry, S., Dérioz, P., Ducourtieux, O., Garambois, N., Gauche, E., Germaine, M.-A., Hiwasaki, L., Letang, M., \& Sacareau, I. (2021). Tourism and "ecoethnicity": the challenges of environmental soft power for minorities in highland Asia (China, Laos, Nepal). Via Tourism Review, 19. https://doi.org/10.4000/viatourism.6625

Lim, H. (2019). Policy Coordination in South Korea. The Korean Journal of Policy Studies, 34(1), 73-97.

Maturbongs, E. E. (2020). Kolaborasi Model Pentahelix Dalam Pengembangan Pariwisata Berbasis Kearifan Lokal Di Kabupaten Merauke. Transparansi : Jurnal Ilmiah Ilmu Administrasi, 3(1), 55-63. https://doi.org/10.31334/transparansi.v3i1.866

Mulyani, S., Fathani, A. T., \& Purnomo, E. P. (2020). Perlindungan Lahan Sawah Dalam Pencapaian Ketahanan Pangan Nasional. Rona Teknik Pertanian, 13(2), 29-41. https://doi.org/10.17969/rtp.v13i2.17173

Neuman, L. (2014). Basic of Social Research: Qualitative and Quantitative Approaches (2nd ed.). Pearson New International. 
Nunkoo, R. (2017). Governance and sustainable tourism: What is the role of trust, power and social capital? Journal of Destination Marketing and Management, 6(4), 277-285. https://doi.org/10.1016/j.jdmm.2017.10.003

Nunkoo, R., \& Gursoy, D. (2012). Residents' support for tourism. Annals of Tourism Research, 39(1), 243-268. https://doi.org/10.1016/j.annals.2011.05.006

Pamungkas, M. D., Zaenuri, \& Wardono. (2021). Ethnomathematics: Geometric analysis of historical buildings ngawen temple in Magelang. Journal of Physics: Conference Series, 1918(4), 0-6. https://doi.org/10.1088/1742-6596/1918/4/042102

Pham Hong, L., Ngo, H. T., \& Pham, L. T. (2021). Community-based tourism: Opportunities and challenges a case study in Thanh Ha pottery village, Hoi An city, Vietnam. Cogent Social Sciences, 7(1), 1-12. https://doi.org/10.1080/23311886.2021.1926100

Pothiban, L., Chintanawat, R., Wongpakaran, N., Srirat, C., \& Sucamwang, K. (2020). Quality of Life of Older People with Dementia in Thailand. Walailak Journal of Science and Technology, 17(10), 1066-1076.

Presenza, A., Abbate, T., \& Micera, R. (2015). The Cittaslow Movement: Opportunities and Challenges for the Governance of Tourism Destinations. Tourism Planning \& Development, 12(4), 479-488. https://doi.org/10.1080/21568316.2015.1037929

Publik, B. K. dan I. (2021). Kemenhub Sampaikan Dukungan Sektor Transportasi di 5 Destinasi Pariwisata Super Prioritas Ke DPR. Dephub.Go.Id. http://dephub.go.id/post/read/kemenhub-sampaikan-dukungan-sektor-transportasi-di-5destinasi-pariwisata-super-prioritas-ke-dpr

Purnomo, E. P., Fathani, A. T., Setiawan, D., Fadhlurrohman, M. I., \& Nugroho, D. H. (2021). Penta-Helix Model in Sustaining Indonesia's Tourism Industry (pp. 477-486). https://doi.org/10.1007/978-3-030-71782-7_42

Ra, A. (2021). Candi Borobudur Jadi Destinasi Wisata Super Prioritas Dapat Dukungan Luar Biasa. Retrieved September 30, 2021, from suarasemarang.poskota.co.id website: https://suarasemarang.poskota.co.id/2021/06/10/candi-borobudur-jadi-destinasi-wisatasuper-prioritas-dapat-dukungan-luar-biasa--

Rahmad Igarta, K. R., \& Handayani, F. (2020). Analisis Spasial Sektor Pariwisata di Provinsi Kalimantan Selatan. Jurnal Borneo Administrator, 16(1), 81-100. https://doi.org/10.24258/jba.v16i1.628

Rasoolimanesh, S. M., \& Jaafar, M. (2016). Community Participation toward Tourism Development and Conservation Program in Rural World Heritage Sites. In Tourism From Empirical Research Towards Practical Application (pp. 76-99). InTech. https://doi.org/10.5772/62293

Renn, O. (2015). Stakeholder and Public Involvement in Risk Governance. International Journal of Disaster Risk Science, 6(1), 8-20. https://doi.org/10.1007/s13753-015-0037-6

Robertson, P. J. (2011). An assessment of collaborative governance in a network for sustainable tourism: The case of redeturis. International Journal of Public Administration, 34(5), 279-290. https://doi.org/10.1080/01900692.2010.550078

Suntikul, W., Pratt, S., Kuan, W. I., Wong, C. I., Chan, C. C., Choi, W. L., \& Chong, O. F. (2016). Impacts of tourism on the quality of life of local residents in Hue, Vietnam. Anatolia: An International Journal of Tourism and Hospitality Research, 27(4), 405-420. https://doi.org/10.1080/13032917.2016.1138234

Tetiwat, O., Esichaikul, V., \& Esichaikul, R. (2019). Requirement Patterns Analysis and Design of Online Social Media Marketing for Promoting Eco-Tourism in Thailand (pp. 277-285). https://doi.org/10.1007/978-3-319-93692-5_27

UNWTO. (2017). Defenition of Sustainable Development of Tourism. United Nations Worlds Tourism Organization. http://sdt.un-wto.org/content/ about-us-5. 
Wibisono, L. (2021). Pulihkan Ekonomi Sektor Pariwisata, Kementerian Pariwisata dan Ekonomi Kreatif Kolaborasi Dengan Grab. Halosemarang.Id. https://halosemarang.id/pulihkan-ekonomi-sektor-pariwisata-kementerian-pariwisatadan-ekonomi-kreatif-kolaborasi-dengan-grab

WONDIRAD, A., Tolkach, D., \& King, B. (2020). Stakeholder collaboration as a major factor for sustainable ecotourism development in developing countries. Tourism Management, 78, 104024. https://doi.org/10.1016/j.tourman.2019.104024

Yi, J., Ryan, C., \& Wang, D. (2021). China's Village Tourism Committees: A Social Network Analysis. Journal of Travel Research, 60(1), 117-132. https://doi.org/10.1177/0047287519892324

Yuwono, E., Maulany, R. I., \& Barkey, R. A. (2021). Site Suitability Evaluation for Ecotourism Development: a Case Study in Bulue Village, Soppeng District, Indonesia. Journal of Sustainability Science and Management, 16(1), 129-140. https://doi.org/10.46754/jssm.2021.01.012

Zolfani, S. H., Sedaghat, M., Maknoon, R., \& Zavadskas, E. K. (2015). Sustainable tourism: A comprehensive literature review on frameworks and applications. Economic ResearchEkonomska Istrazivanja , 28(1), 1-30. https://doi.org/10.1080/1331677X.2014.995895 